\title{
Mononuclear cell therapy attenuates atherosclerosis in apoE KO mice
}

\author{
Marcella L Porto ${ }^{1}$, Leandro CF Lima', Thiago MC Pereira ${ }^{1}$, Breno V Nogueira ${ }^{1}$, Clarissa L Tonini ${ }^{1}$, \\ Bianca P Campagnaro', Silvana S Meyrelles ${ }^{1}$ and Elisardo $\mathrm{C} \mathrm{Vasquez}^{1,2^{*}}$
}

\begin{abstract}
Background: Recent studies have highlighted the potential of cell therapy for atherosclerosis. The aim of this study was to evaluate the effects of mononuclear cell (MNC) therapy on the development of atherosclerotic lesions in the apolipoprotein E knockout (apoE KO) mouse.

Methods: We investigated vascular lipid deposition, vascular remodeling, oxidative stress, and endothelial nitric oxide synthase (eNOS) expression in apoE KO mice treated with spleen MNCs isolated from lacZ transgenic mice (apoE KO-MNC) for 8 weeks compared to untreated control mice (apoE KO).

Results: Histological analysis of aortas showed a significant reduction in the lipid deposition area in apoE KO-MNC mice compared to apoE KO mice (0.051 \pm 0.004 vs $0.117 \pm 0.016 \mathrm{~mm}^{2}$, respectively, $\left.p<0.01\right)$. In addition, vessel morphometry revealed that MNC therapy prevented the outward (positive) remodeling in apoE $\mathrm{KO}$ mice that is normally observed (apoE KO-MNC: $0.98 \pm 0.07$ vs apoE KO: $1.37 \pm 0.09$ ), using wild-type mice (C57BL/6J) as a reference. ApoE KO-MNC mice also have reduced production of superoxide anions and increased eNOS expression compared to apoE KO mice. Finally, immunohistochemistry analysis revealed a homing of endothelial progenitor cells (EPCS) in the aortas of apoE KO-MNC mice.

Conclusion: MNC therapy attenuates the progression of atherosclerosis in the aortas of apoE KO mice. Our data provide evidence that the mechanism by which this attenuation occurs includes the homing of EPCS, a decrease in oxidative stress and an upregulation of eNOS expression.
\end{abstract}

Keywords: cell therapy, atherosclerosis, apoE KO mice, EPC

\section{Background}

Atherosclerosis is a chronic and degenerative disease of the wall of the large arteries and is a leading cause of mortality and morbidity [1,2]. Despite progress in the treatment and repair of this disease, researchers are continually challenged to develop new successful approaches. Therapy using stem/progenitor cells has emerged as an alternative to conventional treatments for atherosclerosis, as demonstrated by some positive results in experimental and clinical studies [3,4].

The apolipoprotein E knockout (apoE KO) mouse, developed two decades ago [5,6], has been used as an

\footnotetext{
* Correspondence: evasquez@pq.cnpq.br

'Laboratory of Transgenes and Cardiovascular Control, Dept. Physiological Sciences, Health Sciences Center, Federal University of Espirito Santo, Vitoria, ES, Brazil

Full list of author information is available at the end of the article
}

experimental model of atherosclerosis because it spontaneously develops hypercholesterolemia and atherosclerosis in a reproducible manner, similar to what is observed in humans. The apoE KO mouse is a particularly useful model as it offers a unique opportunity to evaluate the mechanisms involved in the development of atherosclerosis and new therapies for treatment of this disease.

One potential therapy for atherosclerosis uses mononuclear cells (MNCs), which contain a subpopulation of endothelial progenitor cells (EPCs) [7]. However, the beneficial effects of MNC therapy on atherosclerosis are still a subject of controversy in both humans $[8,9]$ and experimental models of atherosclerosis $[10,11]$. In this regard, the main objective of the current study was to evaluate the effects of MNC therapy on vascular atherosclerotic lesions in apoE $\mathrm{KO}$ mice and to elucidate
C Biomed Central

(C) 2011 Porto et al; licensee BioMed Central Ltd. This is an Open Access article distributed under the terms of the Creative Commons Attribution License (http://creativecommons.org/licenses/by/2.0), which permits unrestricted use, distribution, and reproduction in any medium, provided the original work is properly cited. 
the mechanisms by which MNC therapy attenuates the progression of these lesions. We hypothesized that MNC therapy attenuates the progression of vascular atherosclerosis through the homing of EPCs, reducing reactive oxygen species (ROS), and increasing the expression of endothelial nitric oxide synthase (eNOS).

\section{Materials and methods \\ Animals}

ApoE KO female mice (24-week-old) were randomly divided into two groups: 1) an apoE $\mathrm{KO}$ control group $(\mathrm{n}=8)$ and 2$)$ an apoE $\mathrm{KO}$ group that received MNC therapy (apoE KO-MNC, $\mathrm{n}=8)$. $\beta$-galactosidase $(\beta$-gal) (encoded by the lac $Z$ gene) transgenic mice (12-weekold) were used as MNC donors. Animals were obtained from animal facilities at the Federal University of Espirito Santo. Six-month-old apoE KO mice were fed a cholesterol-rich diet (1.25\% cholesterol) for 4 months and were housed separately in temperature-controlled rooms $\left(22^{\circ} \mathrm{C}\right)$ under a $12 \mathrm{~h}$ light/dark cycle. All procedures were conducted in accordance with the institutional guidelines for animal research and the protocols were previously approved by the Institutional Ethics Committee for Use of Animals (CEUA 003/2008).

\section{Isolation of mononuclear cells from spleen}

Lac Z transgenic mice were euthanized with sodium thiopental overdose $(100 \mathrm{mg} / \mathrm{kg}$, intraperitoneal injection). The spleens were removed, homogenized, and mixed with Dulbecco's Modified Eagle Medium (DMEM) to nourish the cells. The homogenate was then loaded onto a histopaque gradient. The layer containing MNCs was removed and resuspended in DMEM for future intravenous injections.

\section{Transfer of spleen mononuclear cells}

For MNC transfusions, $1 \times 10^{6} \mathrm{MNCs}$ were resuspended in $100 \mu \mathrm{L}$ DMEM and administered by intravenous injections into the tail vein of apoE $\mathrm{KO}$ mice over a period of 2 months ( 1 injection per week for a total of 8 injections). Uninjected apoE $\mathrm{KO}$ mice served as a control group. We included a control group of a age matched apoE KO mice that received vehicle-only (DMEM) injections. To test the preventive effects of MNC therapy, we also administered MNC transfusions to younger (16-week-old) apoE $\mathrm{KO}$ mice that were fed a high-cholesterol diet for 2 months prior to the start of injections.

\section{Measurement of plasma cholesterol levels}

A blood sample $(200 \mu \mathrm{L})$ was collected by intracardiac puncture of each animal and the plasma total cholesterol was measured using a commercial colorimetric kit (Bioclin, Belo Horizonte, Brazil).

\section{Histological analysis of aortic root plaque}

At the end of the experiments, each mouse was euthanized with sodium thiopental overdose $(100 \mathrm{mg} / \mathrm{kg}$, intraperitoneal injection) and the left ventricle was perfused with $0.1 \mathrm{M}$ phosphate-buffered saline (PBS, $\mathrm{pH}$ 7.4) followed by a $4 \%$ formaldehyde solution at a pressure of $100 \mathrm{mmHg}$. The aortic root and a portion of the ascendant aorta were embedded in OCT compound and cross-sectioned on a cryostat (Jung CM1800; Leica, Wetzlar, Germany) at a thickness of $10 \mu \mathrm{m}$. For each animal, aorta cross-sections were mounted on gelatincoated slides and stained with Oil-Red-O (SigmaAldrich, St. Louis, MO, USA) to detect neutral lipids.

\section{Morphometry}

Images of the aorta were captured with a color video camera (VKC150, Hitachi, Tokyo, Japan) connected to a microscope (Olympus AX70, Olympus, Center Valley, PA, USA) and analyzed using a National Institute of Health (NIH) Image program. An examiner blinded to the experimental groups performed the image analysis to prevent any bias is the interpretation of the results. Using a $4 \times$ objective, the vessel cross-sectional area $\left(\mathrm{V}_{\mathrm{CSA}}\right)$ and the lumen cross-sectional area were calculated. The vascular remodeling ratio was obtained by dividing each animal's $\mathrm{V}_{\mathrm{CSA}}$ by the average $\mathrm{V}_{\mathrm{CSA}}$ of wild-type C57BL/6J (C57) mice and each sample was scored for absence of remodeling (0.95-1.05), inward remodeling $(<0.95)$, or outward remodeling $(>1.05)$.

\section{Localization of donor MNCs}

The remaining whole aorta was opened lengthwise and stained en face for donor MNC localization. Aortic samples were incubated for $12 \mathrm{~h}$ at $37^{\circ} \mathrm{C}$ in freshly prepared $\beta$-gal staining solution ( $\mathrm{pH} 4.0$ ) containing $2.4 \mathrm{mM} 5$ bromo-4-chloro-3-indolyl-D-galactopyranoside (X-gal, Sigma Aldrich), $4.7 \mathrm{mmol} / \mathrm{L}$ potassium ferrocyanide, 4.9 $\mathrm{mmol} / \mathrm{L}$ potassium ferricyanide, $150 \mathrm{mmol} / \mathrm{L} \mathrm{NaCl}, 1$ $\mathrm{mmol} / \mathrm{L} \mathrm{MgCl}_{2}$ and $40 \mathrm{mmol} / \mathrm{L}$ citric acid.

\section{Detection of superoxide production}

Unfixed frozen sections of aorta were incubated in 2 $\mu$ mol dihydroethidium (DHE) modified Kreb's solution containing $20 \mathrm{mmol}$ of HEPES for $30 \mathrm{~min}$ in a lightprotected chamber at $37^{\circ} \mathrm{C}$.

\section{Immunohistochemistry}

Cross-sections $(10 \mu \mathrm{m})$ were cut on a cryostat and placed on gelatin-coated slides. Sections were air-dried and then slides were fixed for 20 minutes in acetone at $-20^{\circ} \mathrm{C}$. Slides were incubated with the following primary antibodies overnight: eNOS, 1:50 (BD Pharmingen, San Diego, CA, USA); vascular endothelial grown factor receptor (Flk-1), 1:50 (Abcam, Cambridge, MA, USA); 
hematopoietic stem cell antigen (CD133), 1:50 (Millipore, Billerica, MA, USA). A Vectastain ABC Elit kit was used for detection, with DAB or NovaRED staining (Vector Laboratories, Burlingame, CA, USA).

\section{Statistical Analysis}

Data are presented as the mean \pm SEM. Statistical analysis was performed with Student's $t$-test for independent samples. One-way analysis of variance (ANOVA), followed by the Tukey post hoc test for multiple comparisons, was used when appropriate. Statistical significance was set at $\mathrm{p}<0.05$.

\section{Results}

Plasma total cholesterol levels of 24-week-old animals that were fed a high-cholesterol diet for 16 weeks was similar between apoE $\mathrm{KO}$ control mice and apoE KO mice that received MNC therapy for 8 weeks (1176 \pm 213 vs. $1241 \pm 167 \mathrm{mg} / \mathrm{dL} ; \mathrm{p}>0.05)$.

Figure 1 shows the effect of MNC therapy on vessel lipid deposition. As shown by the histological analysis of a typical aortic root cross-section, apoE KO-MNC mice demonstrated marked reduction of the atherosclerotic lesion. A large lipid deposition area was observed in the aorta roots of 24-week-old apoE $\mathrm{KO}$ control and vehicle-only mice $\left(0.117 \pm 0.016 \mathrm{~mm}^{2}\right.$ and $0.109 \pm 0.012$

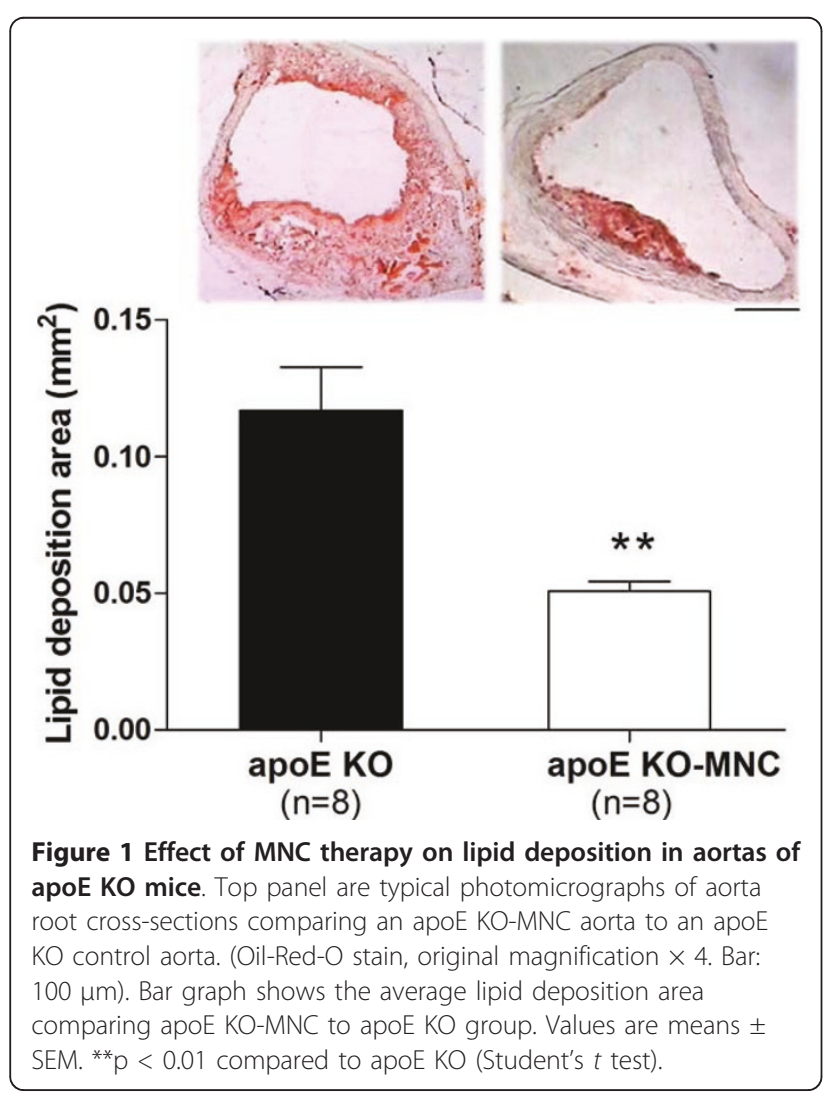

$\mathrm{mm}^{2}$, respectively). In contrast, the lipid deposition area was significantly reduced in approximately $45 \%$ ( $\mathrm{p}<$ 0.01) of age-matched apoE KO-MNC mice (bar graph, Figure 1). This value of apoE KO-MNC was statistically similar to that observed in 16-week-old apoE KO mice (0.051 \pm 0.004 vs. $0.049 \pm 0.005 \mathrm{~mm}^{2}$, respectively), indicating that MNCs have atheroprotective properties.

Figure 2 summarizes data obtained from measurements of the aorta cross-sectional area and vascular remodeling in apoE $\mathrm{KO}$ and apoE KO-MNC mice, using wild-type C57 animals as reference values. The vessel lumen area was statistically similar in all groups analyzed. However, the vessel wall area was significantly increased in apoE KO mice $\left(0.79 \pm 0.05 \mathrm{~mm}^{2}\right)$ compared to C57 mice $\left(0.37 \pm 0.05 \mathrm{~mm}^{2}, \mathrm{p}<0.01\right)$. This increase was subsequently normalized by MNC therapy (apoE KO-MNC: $0.39 \pm 0.04 \mathrm{~mm}^{2}, \mathrm{p}<0.01$ ). Consistent with this finding, the positive $(>1.05)$ vascular remodeling observed in apoE KO mice was prevented by MNC therapy (ratios of $1.37 \pm 0.09$ in apoE KO vs. $0.98 \pm 0.07$ in apoE KO-MNC).

Figure 3 shows typical en face aortas from apoE KO and apoE KO-MNC mice that were stained with $\beta$-gal to identify donor-derived MNCs. All apoE KO animals that received MNC therapy from lacZ transgenic mice expressed $\beta$-gal staining in the aorta roots when compared with untreated and vehicle-only mice (data not shown), which lacked any vessel $\beta$-gal staining.

To investigate the mechanisms by which MNC therapy reduced atherosclerosis, we evaluated superoxide $\left(\mathrm{O}_{2}{ }^{--}\right)$production, eNOS production, and homing of endothelial progenitor cells. As illustrated in the microphotographs in Figure 4 (top panel), a dihydroethidium oxidative assay revealed intense ethidium fluorescence

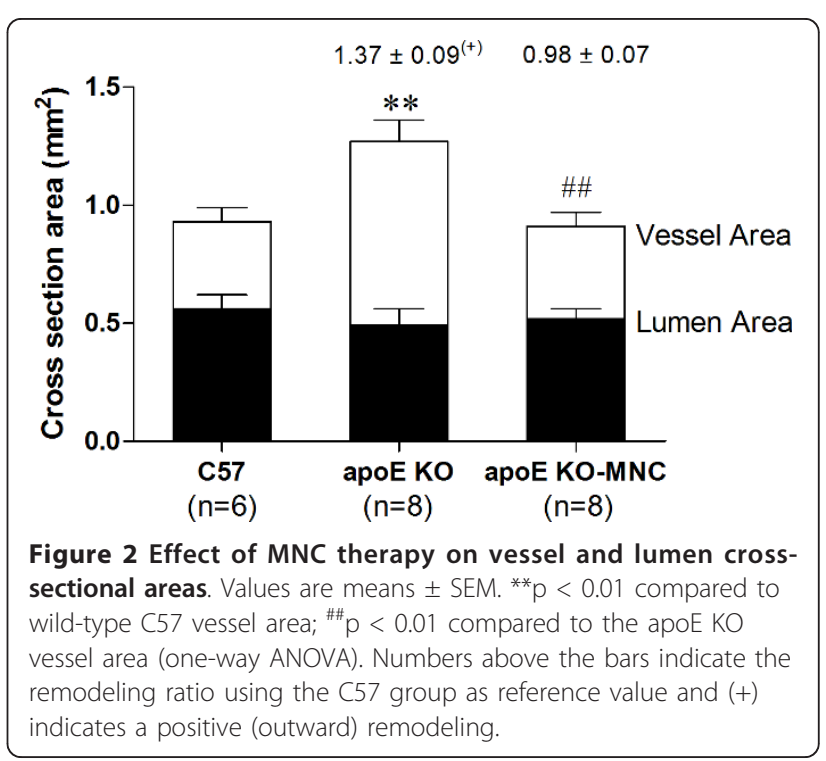




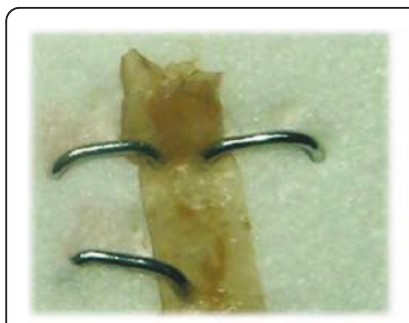

apoE KO

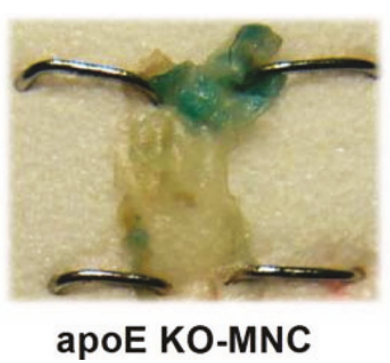

apoE KO-MNC
Figure 3 Typical photograph of an aorta root stained en face showing $\beta$-gal-positive cells (blue) derived from lac $Z$ mice in the apoE KO-MNC mouse, compared to the lack of staining in the apoE KO mouse.

in the apoE $\mathrm{KO}$ mouse but not in the apoE KO-MNC mouse. On average, the aortas from apoE KO-MNC mice exhibited approximately $60 \%$ less ethidium fluorescence than untreated apoE KO mice (Figure 4, bottom panel). In addition, qualitative immunohistochemistry in aortas from apoE KO-MNC revealed increased expression of eNOS compared to untreated apoE KO mice (Figure 5). Homing of endothelial progenitor cells was confirmed by immunohistochemistry detection of Flk-1 and CD133, markers of endothelial progenitor cells, which showed a marked increase in Flk-1 and CD133

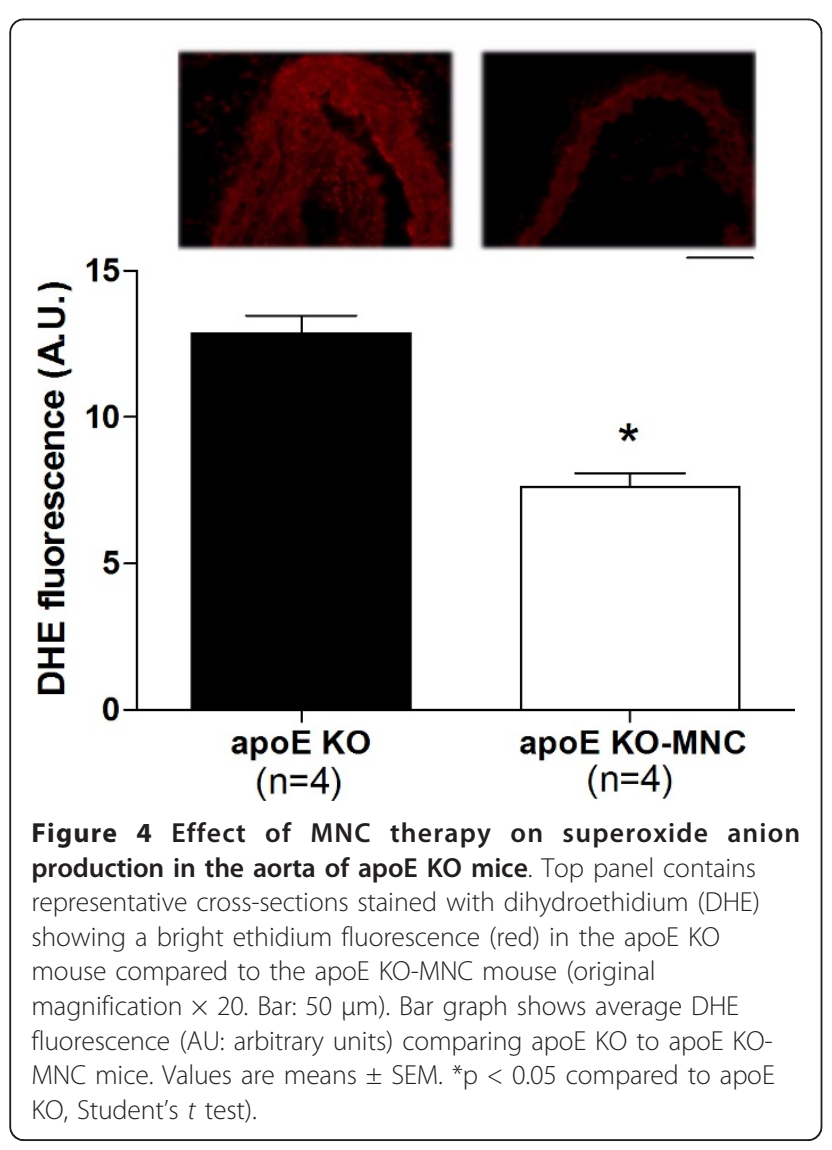

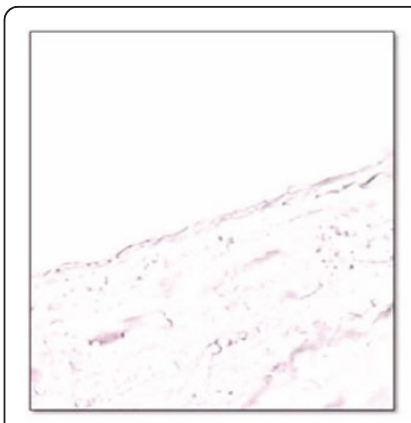

apoE KO

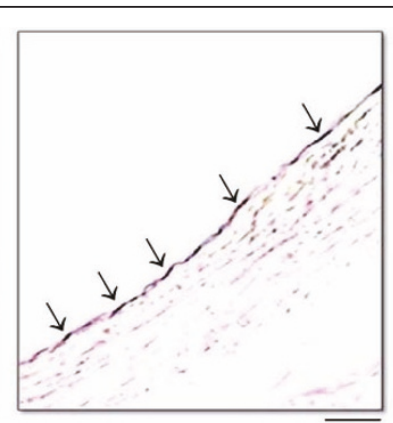

apoE KO-MNC
Figure 5 Effect of MNC therapy on eNOS protein production in aortas of apoE KO mice. Representative microphotographs reveal a positive immunoreaction (brown precipitates, indicated by arrow) for eNOS in the endothelium of the apoE KO-MNC mouse

compared to the apoE KO mouse. (DAB stain, original magnification $\times 20$. Bar: $50 \mu \mathrm{m})$.

staining in the aorta endothelium of apoE KO-MNC mice compared to untreated apoE $\mathrm{KO}$ mice (illustrations in Figure 6).

\section{Discussion}

In the present study we observed that 8 weeks of MNC therapy resulted in the attenuation of atherosclerotic lesions in aortas from apoE KO mice through the homing of EPCs, a reduction in the production of superoxide anions and an increase in eNOS expression.

Stem/progenitor cells, a subpopulation of MNCs, have unique characteristics that make them ideal for therapeutic purposes. They are undifferentiated, unspecialized, and can divide symmetrically and asymmetrically for long periods [12-14]. In the present study we observed that MNCs have atheroprotective properties in

Flk-1
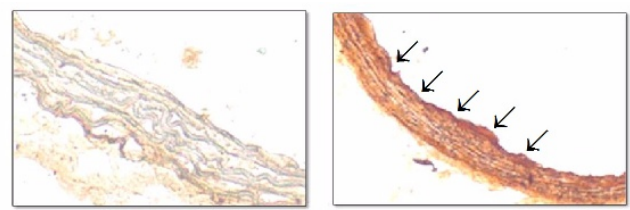

CD133

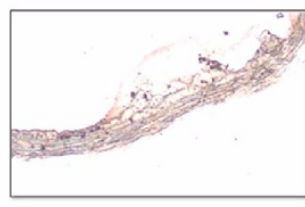

apoE KO

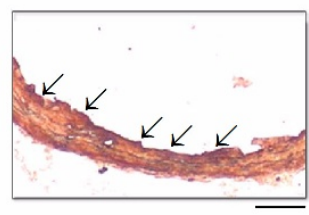

apoE KO-MNC

Figure 6 Homing of endothelial progenitor cells after MNC therapy in apoE KO mice. Photomicrographs are typical aorta cross-sections stained for the markers Flk-1 (vascular endothelial growth factor receptor) and CD133 (hematopoietic stem cell antigen) showing an intense immune reaction (red precipitate) in MNC-treated animals. (original magnification $\times 20$. Bar: $50 \mu \mathrm{m}$ ). 
an apoE $\mathrm{KO}$ murine model of atherosclerosis, even under conditions of high total cholesterol in the plasma. The development of atherosclerosis was accelerated by a high-cholesterol diet; however, continuous treatment with MNCs derived from young lacZ transgenic mice caused a marked attenuation of the atherosclerotic lesion, without affecting the high total cholesterol levels in the plasma. This finding is in agreement with other studies in aortas $[10,15]$ and carotid arteries [16] from murine models of atherosclerosis but conflicts with one study which found no significant effects from MNC therapy on atherosclerosis [17] and two studies which observed opposite results to ours $[11,18]$. This discrepancy could be due to the different methods used in these studies. For example, the study that found that there was no benefit from MNC therapy [17] treated the animals with fewer injections of MNCs ( 1 to 3 injections at similar concentrations) than did we and others $[10,15]$ who observed a beneficial effect (6 to 8 injections). Other variable factors include the animal's age and gender.

The vascular remodeling of large arteries is considered an adaptive structural change that occurs in response to a variety of conditions, including atherosclerosis $[19,20]$. Our finding of a positive (outward) remodeling in aortas from apoE KO control mice corroborates this adaptive morphological change and is in agreement with previous studies [21-23]. A novel finding of this study revealed that animals that received MNC therapy (apoE KOMNC mice) did not show vascular positive remodeling, most likely as a direct consequence of marked attenuation of the atherosclerotic process.

The X-gal en face analysis of aortas from apoE KO mice revealed the presence of donor MNCs (from a lac $Z$ mouse) in atherosclerotic areas, indicating that the therapeutic effect of MNCs is at the level of the arterial wall, as has been described by others $[10,24,25]$. We then investigated the possible mechanisms by which MNCs could locally mediate the attenuation of atherosclerosis in apoE KO mice.

It is known that the number of circulating EPCs is inversely proportional to the risk of cardiovascular diseases [26], suggesting that increasing the number of circulating EPCs could be a powerful therapy in the treatment of atherosclerosis $[10,27]$. Based on what has been done in other studies [28], we used the spleen as a source of EPCs, which are contained within the mononuclear fraction. Our hypothesis that EPCs derived from the MNC fraction are involved in the anti-atherogenic response is based on our discovery of vascular homing of EPCs and the presence of markers Flk-1 and CD133 in aortas from apoE $\mathrm{KO}$ mice treated with MNCs $[29,30]$. As shown in Figure 6, aorta cross-sections from
apoE KO-MNC mice showed intense expression of EPC markers. This indicates that in the presence of EPCs, the vessel wall is capable of accelerating the re-endothelialization and inhibition of neointimal formation. This mechanism of action by EPCs has also been demonstrated by others [31].

Clinical and experimental studies of atherosclerosis, including those using the apoE KO mouse model, support the concept that overabundance of ROS and/or a decline in antioxidant ability plays a causal role in atherosclerosis [32,33]. Moreover, the integrity of eNOS/NO production in the vasculature is critical for normal vascular function [34]. The effects of cell therapy on ROS production have not previously been studied in experimental atherosclerosis. To address this, in the present study we tested the hypothesis that the beneficial effects of MNC includes a reduction in oxidative stress. We found that MNC therapy in apoE KO mice resulted in a marked decrease in $\mathrm{O}_{2}^{--}$production and a concomitant upregulation of eNOS in the aorta, supporting the idea that another important mechanism by which MNC therapy attenuates the progression of atherosclerosis is by relieving oxidative stress. Thus, we speculate that the increased number of circulating EPCs provided by MNC therapy upregulated the NO pathway. This finding is consistent with other studies that observed similar results in a model of experimental diabetes [35].

In conclusion, we have shown that MNC therapy attenuates atherosclerotic lesions in aortas from apoE $\mathrm{KO}$ mice. Our data provide evidence that the mechanisms by which MNC therapy is atheroprotective include homing of EPCs, reducing $\mathrm{O}_{2}^{--}$production and upregulating eNOS expression. Although further studies are needed to reveal additional mechanisms underlying the atherosclerotic process in this murine model, the present data provide important evidence on the beneficial effect of cell therapy on atherosclerosis.

\section{Acknowledgements}

This research was supported by the National Council for the Development of Science and Technology (CNPq) and State Agency for the Development of Science and Technology (FAPES: PRONEX 012/2009).

\section{Author details}

'Laboratory of Transgenes and Cardiovascular Control, Dept. Physiological Sciences, Health Sciences Center, Federal University of Espirito Santo, Vitoria, ES, Brazil. 'Emescam College of Health Sciences, Vitoria, ES, Brazil.

\section{Authors' contributions}

MLP carried out experimental analysis and acquisition of data, analysis and interpretation of the data and drafted the manuscript. LCF carried out the experimental analysis. TMCP performed the statistics analysis and helped to draft the manuscript. BVN contributed to histology. CLT and BPC

participated in the study's design and supervision and in the critical revision of the manuscript. SSM and ECV contributed to the conception, design and supervision of the study and interpretation of data. All authors read and approved the final version of the manuscript. 


\section{Competing interests}

The authors declare that they have no competing interests.

Received: 30 August 2011 Accepted: 6 September 2011 Published: 6 September 2011

\section{References}

1. Ross R: Rous-Whipple Award Lecture: Atherosclerosis: a defense mechanism gone awry. Am J Pathol 1993, 143(4):987-1002.

2. Libby P, Ridker PM, Hansson GK: Progress and challenges in translating the biology of atherosclerosis. Nature 2011, 473(7347):317-25.

3. Chade AR, Zhu X, Lavi R, Krier JD, Pislaru S, Simari RD, Napoli C, Lerman A, Lerman LO: Endothelial progenitor cells restore renal function in chronic experimental renovascular disease. Circulation 2009, 119(4):547-57.

4. Dotsenko O: Stem/Progenitor cells, atherosclerosis and cardiovascular regeneration. Open Cardiovasc Med J 2010, 4:97-104.

5. Plump AS, Smith JD, Hayek T, Aalto-Setälä K, Walsh A, Verstuyft JG, Rubin EM, Breslow JL: Severe hypercholesterolemia and atherosclerosis in apolipoprotein E-deficient mice created by homologous recombination in ES cells. Cell 1992, 71(2):343-53.

6. Piedrahita JA, Zhang SH, Hagaman JR, Oliver PM, Maeda N: Generation of mice carrying a mutant apolipoprotein $\mathrm{E}$ gene inactivated by gene targeting in embryonic stem cells. Proc Natl Acad Sci USA 1992, 89(10):4471-5.

7. Zampetaki A, Kirton JP, Xu Q: Vascular repair by endothelial progenitor cells. Cardiovasc Res 2008, 78(3):413-21.

8. van Ramshorst J, Bax JJ, Beeres SL, Dibbets-Schneider P, Roes SD, Stokkel MP, de Roos A, Fibbe WE, Zwaginga JJ, Boersma E, Schalij MJ, Atsma DE: Intramyocardial bone marrow cell injection for chronic myocardial ischemia: a randomized controlled trial. JAMA 2009, 301(19):1997-2004

9. Hopp E, Lunde K, Solheim S, Aakhus S, Arnesen H, Forfang K, Edvardsen T, Smith HJ: Regional myocardial function after intracoronary bone marrow cell injection in reperfused anterior wall infarction - a cardiovascular magnetic resonance tagging study. J Cardiovasc Magn Reson 2011, 13:22

10. Rauscher FM, Goldschmidt-Clermont PJ, Davis BH, Wang T, Gregg D, Ramaswami P, Pippen AM, Annex BH, Dong C, Taylor DA: Aging, progenitor cell exhaustion, and atherosclerosis. Circulation 2003, 108(4):457-63.

11. Silvestre JS, Gojova A, Brun V, Potteaux S, Esposito B, Duriez M, Clergue M,

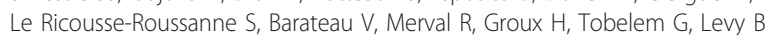
Tedgui A, Mallat Z: Transplantation of bone marrow-derived mononuclear cells in ischemic apolipoprotein E-knockout mice accelerates atherosclerosis without altering plaque composition. Circulation 2003, 108(23):2839-42.

12. Yagita Y, Kitagawa K, Ohtsuki T, Takasawa Ki, Miyata T, Okano H, Hori M, Matsumoto M: Neurogenesis by progenitor cells in the ischemic adult rat hippocampus. Stroke 2001, 32(8):1890-6.

13. Yang Z, Di Santo S, Kalka C: Current developments in the use of stem cell for therapeutic neovascularisation: is the future therapy "cell-free"? Swiss Med Wkly 2010, 140:w13130.

14. Przybycień K, Kornacewicz Jach Z, Machaliński B: Stem cells in cardiological clinical trials. Kardiol Pol 2011, 69(6):601-9, Polish.

15. Nelson WD, Zenovich AG, Ott HC, Stolen C, Caron GJ, PanoskaltsisMortari A, Barnes SA, Xin X, Taylor DA: Sex-dependent attenuation of plaque growth after treatment with bone marrow mononuclear cells. Circulation 2007, 101(12):1319-27.

16. Werner N, Priller J, Laufs U, Endres M, Böhm M, Dirnagl U, Nickenig G: Bone marrow-derived progenitor cells modulate vascular reendothelialization and neointimal formation: effect of 3-hydroxy-3-methylglutaryl coenzyme a reductase inhibition. Arterioscler Thromb Vasc Biol 2002, 22(10):1567-72.

17. Wassmann S, Werner N, Czech T, Nickenig G: Improvement of endothelial function by systemic transfusion of vascular progenitor cells. Circulation 2006, 99(8):e74-83.

18. George J, Afek A, Abashidze A, Shmilovich H, Deutsch V, Kopolovich J, Miller $\mathrm{H}$, Keren G: Transfer of endothelial progenitor and bone marrow cells influences atherosclerotic plaque size and composition in apolipoprotein E knockout mice. Arterioscler Thromb Vasc Biol 2005, 25(12):2636-41.
19. Glagov S, Weisenberg E, Zarins CK, Stankunavicius R, Kolettis GJ: Compensatory enlargement of human atherosclerotic coronary arteries. N Engl J Med 1987, 316(22):1371-5.

20. Langille BL: Arterial remodeling: relation to hemodynamics. Can J Physiol Pharmacol 1996, 74(7):834-41.

21. Lutgens E, de Muinck ED, Heeneman S, Daemen MJ: Compensatory enlargement and stenosis develop in apoE(-/-) and apoE*3-Leiden transgenic mice. Arterioscler Thromb Vasc Biol 2001, 21(8):1359-65.

22. Nogueira BV, Peotta VA, Meyrelles SS, Vasquez EC: Evaluation of aortic remodeling in apolipoprotein E-deficient mice and renovascular hypertensive mice. Arch Med Res 2007, 38(8):816-21.

23. Pereira TM, Nogueira BV, Lima LC, Porto ML, Arruda JA, Vasquez EC, Meyrelles SS: Cardiac and vascular changes in elderly atherosclerotic mice: the influence of gender. Lipids Health Dis 2010, 9:87.

24. Hu Y, Mayr M, Metzler B, Erdel M, Davison F, Xu Q: Both donor and recipient origins of smooth muscle cells in vein graft atherosclerotic lesions. Circulation 2002, 91(7):e13-20.

25. Foteinos G, Hu Y, Xiao Q, Metzler B, Xu Q: Rapid endothelial turnover in atherosclerosis-prone areas coincides with stem cell repair in apolipoprotein E-deficient mice. Circulation 2008, 117(14):1856-63.

26. Schmidt-Lucke C, Fichtlscherer S, Aicher A, Tschöpe C, Schultheiss HP, Zeiher AM, Dimmeler S: Quantification of circulating endothelial progenitor cells using the modified ISHAGE protocol. PLOS One 2010, 5(11):e13790.

27. Strehlow K, Werner N, Berweiler J, Link A, Dirnagl U, Priller J, Laufs K Ghaeni L, Milosevic M, Böhm M, Nickenig G: Estrogen increases bone marrow-derived endothelial progenitor cell production and diminishes neointima formation. Circulation 2003, 107(24):3059-65.

28. Patschan D, Krupincza K, Patschan S, Zhang Z, Hamby C, Goligorsky MS: Dynamics of mobilization and homing of endothelial progenitor cells after acute renal ischemia: modulation by ischemic preconditioning. Am J Physiol Renal Physiol 2006, 291(1):F176-85.

29. Purpura KA, George SH, Dang SM, Choi K, Nagy A, Zandstra PW: Soluble Flt-1 regulates Flk-1 activation to control hematopoietic and endothelial development in an oxygen-responsive manner. Stem Cells 2008, 26(11):2832-42.

30. Corbeil D, Röper K, Weigmann A, Huttner WB: AC133 hematopoietic stem cell antigen: human homologue of mouse kidney prominin or distinct member of a novel protein family? Blood 1998, 91(7):2625-6.

31. Umemura T, Higashi Y: Endothelial progenitor cells: therapeutic target for cardiovascular diseases. J Pharmacol Sci 2008, 108(1):1-6

32. Kawashima S: Malfunction of vascular control in lifestyle-related diseases: endothelial nitric oxide (NO) synthase/NO system in atherosclerosis. J Pharmacol Sci 2004, 96(4):411-9.

33. Kunitomo M: Oxidative stress and atherosclerosis. Yakugaku Zasshi 2007, 127(12):1997-2014

34. Davignon J, Ganz P: Role of endothelial dysfunction in atherosclerosis. Circulation 2004, 109(23 Suppl 1):III27-32.

35. Sambuceti G, Morbelli S, Vanella L, Kusmic C, Marini C, Massollo M, Augeri C, Corselli M, Ghersi C, Chiavarina B, Rodella LF, L'Abbate A, Drummond G, Abraham NG, Frassoni F: Diabetes impairs the vascular recruitment of normal stem cells by oxidant damage, reversed by increases in PAMPK, heme oxygenase-1, and adiponectin. Stem Cells 2009, 27(2):399-407.

doi:10.1186/1476-511X-10-155

Cite this article as: Porto et al.: Mononuclear cell therapy attenuates atherosclerosis in apoE KO mice. Lipids in Health and Disease 2011 10:155. 